\title{
The First "Sound of the Aura" of Hermeto Pascoal (1984): Hearing the Spoken Voice as a Sung Melody
}

\author{
Luiz Costa-Lima Neto \\ Escola de Música Villa-Lobos \\ costalimaneto.luiz@gmail.com
}

\section{Translator: Tom Moore}

\begin{abstract}
This article explores the "Som da Aura", a term created by the Brazilian composer and multi-instrumentalist Hermeto Pascoal to designate musical compositions based on the notion that the spoken voice is a non-conventional melody. I show how the "Sound of the Aura" derived from Hermeto's intuitive childhood experimentations with the sounds of his environment, later developed into the musical use of unconventional sound patterns, such as human speech, discerned by Hermeto with his accurate hearing. I analyze the antecedents, the context and the music of the first "Sound of the Aura" to be recorded, the piece "Tiruliruli" (1984), originally a narration done by the sports announcer Osmar Santos about a goal by the soccer player, "Doutor" Sócrates. The article discusses the dichotomy between the "natural" and the "conventional", used by the composer in order to structure the "Sound of the Aura", addressing musical, psychological, sociocultural, economic and spiritual aspects.
\end{abstract}

KEYWORDS: Experimentalism, voice, perfect pitch, microtonality, soccer, spirituality, nature.

\section{Introduction}

I say speech, but it is singing. I say speech only as a reference because people are still not used to it. (Hermeto Pascoal, 1999. Personal interview, Rio de Janeiro, 6 March). 
In 1984, the Brazilian composer and multi-instrumentalist Hermeto Pascoal (born in June 22, 1936) launched the composition entitled "Tiruliruli" (Som Da Gente 1984), originally a presentation made by the sports announcer Osmar Santos based on a goal by the famous soccer player, "Doutor" Sócrates, who spent the majority of his career (1978 to 1984) with Sport Club Corinthians Paulista, and played for Brazil in two World Cups $(1982,1986)$ (1). "Tiruliruli" was the first recorded "Sound of the Aura", a term created by Hermeto Pascoal based on the notion that speech is a non-conventional melody:

\begin{abstract}
Music that is called atonal is almost the music that I call 'Sound of the Aura'. There are a lot of people who think that C, E, G, C is natural, but no, it is only conventional. Because the atonal is the most natural thing that exists. (...) I am the inverse of many schools, the majority of things that they call tonal, I call atonal, I call them the opposite. From my perspective, if you do: (sings) B-flat1, E3, A-flat2, E2, Bflat1, A2, that is natural, for this one has the 'Sound of the Aura'. (Hermeto Pascoal, 1999. Personal interview, Rio de Janeiro, 6 March).
\end{abstract}

In addition to "Tiruliruli", other examples of the "Sound of the Aura" recorded on the LPs and CDs of Hermeto Pascoal are: "Vai mais, garotinho" (Lagoa da Canoa - Município de Arapiraca, Som Da Gente 1984); "Pensamento positivo", "Três coisas", "Aula de natação", "Quando as aves se encontram nasce o som" (Festa dos Deuses, Polygram 1992), and "Som da Aura" (Mundo dos sons, Selo SESC 2017). Hermeto Pascoal performs the "Sound of the Aura" of the Blind Singers of Paraíba (see dir. Berliner 2004), of the French actor Yves Montand (see dir. Billon 1997), and of a vendor at a Japanese market (in "Feira de Asakusa")(Cherry Red Records 2008). Hermeto(2) also did the "Sound of the Aura" of soap opera actresses (Ângela Leal), talk show hosts (Jô Soares), music teachers (Hankus Netsky), and even Pope John Paul II, but these last examples were not released commercially.

Although he is identified principally as a composer and multi-instrumentalist, Hermeto Pascoal has used the voice on several of his compositions appearing on his discs recorded from 1972 until now. Whether singing and simultaneously playing conventional and unconventional instruments, exploring the purely sonorous values of the words, improvising narrations and lyrics, or imitating the sounds of animals or conversing with spirits (Pascoal 2000), the voice has always been present from the beginning of Hermeto's solo career. Out of a total of 152 pieces of music recorded on the 13 discs released under his name between 1972 and 2002, the voice (that of Hermeto Pascoal himself and of other performers) is present in about 90 compositions, corresponding to approximately sixty per cent of the total. In fact, Hermeto Pascoal's voice appears on commercial recordings from before his first LP Hermeto (Buddah Records 1972), for example, on the LP Live Evil (Sony 1972) by Miles Davis (recorded in 1970 and issued in 1972), and on the LPs Natural Feelings (Buddah Records 1970) and Seeds on the ground (One Way Records 1971) by Airto. One may also mention the composition titled "O Ovo" ("The egg"), recorded on the LP by the Quarteto Novo (EMI 1967), for which Hermeto would write lyrics, years after the disc was recorded, that went back to a popular poetic tradition of a prolific and enchanted nature:

I have a hen that lays a hundred eggs a month, but I can't understand, 'cause they come three at a time. In my yard I had fifty thousand hens, I sold them all to my neighbor, Mariquinha. Now I've only got a little chick, I've started all over again, with an egg. (Hermeto Pascoal, "The Egg"). 
For Hermeto there is no separation between voice and instrument, since, as made evident by the following quotation, not only is the voice an instrument, but it is the "richest" instrument that exists:

Why is the voice the richest instrument that there is? Because it has all the tonalities, it is entirely natural. You can do a thing in any tonality that you want, you can even do something between one pitch and another. That is, when you play a lot of people still have that traditionalism, those things of saying that it has to be that way. What people call speech is what we are singing.

(dir. Berliner 2004)

In the two passages above one can note the dichotomy between the "natural" and the "conventional", two categories that Hermeto Pascoal uses to structure his musical creation (Costa-Lima Neto 2000). For him, the voice is the most "natural" instrument. Playing is associated for Hermeto Pascoal with traditionalism, while the voice, on the other hand, escapes convention and the traditional, since it is an instrument that is able to produce frequencies in any tonality and also between the notes of the equal-tempered system.

As the term the "Sound of the Aura" suggests, the sonorous and musical aspect here appears to be related to a spiritual dimension. According to Hermeto Pascoal, known publicly in Brazil as the "wizard" or "shaman" (mago or bruxo):

The Sound of the Aura is the sonorous vibration of the soul of each person, reflected in his speech, which makes the connection between mind and body. It is also possible to make the sound of the aura of animals and of objects. In the case of objects, they reflect our energy. (hermetopascoal.com.br)

Perhaps due to impaired vision caused by albinism, Hermeto Pascoal uses a synesthetic metaphor to define the musician of the aura: he is like a 'photographer of sound', who clicks the sonorous moment through recording, develops the negative of the sound which has been recorded - decoding the melody of speech - and modifies the enlarged image by impressing his own imagination upon the recording on the disc, through the addition of harmonies and arrangements. According to pianist and composer Jovino Santos Neto (2009, Personal communication), who was a member of the bands that accompanied Hermeto in the period 1977-1993, the musician of the aura should be able to "listen profoundly, capturing the smallest musical nuances" so as to perceive the pitches, durations, intensities, and timbres of the spoken voice (the "melody").

In this article, I will address the antecedents and the context of "Tiruliruli", the first "Sound of the Aura" to be created by Hermeto Pascoal, in addition to analyzing and transcribing the track from the LP recording. The article will discuss how Hermeto uses the dichotomy between the "natural" and the "conventional" in order to structure the "Sound of the Aura", aiming to transform the familiar into the exotic, and the terrestrial into the transcendent, as a kind of a musical utopia.

\section{The antecedents of the first "Sound of the Aura"}

Hermeto Pascoal was born in Olho d'Água da Canoa, Alagoas, a small village near the town of Lagoa da Canoa, in the municipality of Arapiraca, on 22 June 1936. Ever since he was a child, the universe of sound has been a constant source of pleasure for him, and a powerful stimulus not only for fun but also for creativity. 
His first musical experiences were playing pifes ("reed pipes") that he made himself with leaves from the castor-oil tree or with squash leaves, and composing short tunes through beating on pieces of iron belonging to his blacksmith grandfather.

As a little boy, at the age of seven, I was already in contact with music. My father played an accordion with eight bass buttons, and I played pife that I made myself, there in the forest, with cane. Since I was albino, I could not be exposed to the sun. (...) When my father used to take me to the field, in the oxcart, I would try to make some little flutes to play with the birds. And when he came back, he would see that the tree was full of birds. Since then, whenever I play somewhere that has a bird, I am able to communicate with them. (Hermeto Pascoal, 1999. Personal interview, Rio de Janeiro, 6 March).(3)

When he was eight years old, he began playing his father's eight-bass accordion (also known in the Northeast as the pé de bode or literally, goat's hoof), and, from the age of twelve, the 32 bass accordion. With his father and brother, Hermeto Pascoal then began to play tambourine and accordion at wedding parties and forrós popular balls in Alagoas. In 1950, Hermeto Pascoal ran away from home to try his luck as an accordionist in the city of Recife, capital of the State of Pernambuco and an important cultural centre in the Northeast. At the end of the 1950s, while he was teaching himself to play various instruments, the musician migrated to the two largest cities in Brazil, Rio de Janeiro and São Paulo, in the Southeast region of the country. In 1970, he moved to the US, where he began working as a composer, returning to Brazil finally in 1980, after many international comings and goings (Costa-Lima Neto 2011).

The roots of the "Sound of the Aura" can be found in Pascoal's childhood, when the boy began to listen to peoples' speech as a sung melody, an ability not understood by his parents, who called him aluado ("lunatic, crazy"): "My mother was talking with a friend of hers and suddenly I said: 'Mother, she is singing.' And my mother said: 'My son, what is this, are you a lunatic?'" (Hermeto Pascoal, 1997. Personal interview, Rio de Janeiro, 10 November).

The "Sound of the Aura" thus has a long history, beginning well before "Tiruliruli", launched in 1984, when Hermeto Pascoal was forty-eight. Various examples suggest that the musician had already been sketching out the "Sound of the Aura" from the beginning of his solo career in the 1970s. For example, on the first LP issued in the USA Hermeto (Buddah Records 1972), at the beginning of the song "Velório" ("Mourning"), vocal whispers and murmurs dialogue with dissonant chords played by a set of bottles. On his LP A música livre de Hermeto Paschoal (Polygram 1973), the first to be recorded in Brazil, at the end of the composition "Sereiarei", Hermeto Pascoal seems to make the "Sound of the Aura" of the sounds of animals (pigs, geese, turkeys, chickens, ducks, and rabbits), which appear in combination with the sounds of the instruments of the orchestra. On the same LP, at the end of "O Gaio da roseira" ("The Rose Stem"), he explores the musicality of the spoken voice, improvising words together with the musicians of the orchestra. On his LP Slaves Mass (Warner 1977), in the coda of "Slaves Mass", there is an unusual vocal duo between the singer Flora Purim and two pigs, while in "Escuta meu piano" ("Listen to my Piano"), in turn, Hermeto Pascoal sings and plays simultaneously, in an improvised way, fusing his voice with the sound of the piano. In the 1979 LP Hermeto Pascoal ao vivo em Montreux (WEA Brasil 1979a), during the improvised vocal-instrumental solo of "Quebrando tudo" ("Breaking all"), Hermeto Pascoal seems to transpose the pitches of the shouts and laughs of his 
voice to the Fender Rhodes; while in the LP Cérebro magnético (WEA Brasil 1980), in the song "Dança da Selva na Cidade Grande" ("Jungle Dance in Big City"), the musicians of the Group use their voices in a sort of spoken song, following the text created by Hermeto Pascoal. Finally, in the song "Cores" "Colours") (Hermeto Pascoal e Grupo, Som da Gente 1982), in which he synesthetically compares the noisy and microtonal sound of the cicada to the rainbow - the non-tempered song of the of insect dialogues with the conventional instruments, with nature and culture traversing a continuum, in a manner similar to that which takes place in the "Sound of the Aura".

The examples above demonstrate that something paradoxical took place: while his biological age increased, at the same time Hermeto Pascoal was retrieving sound elements related to his childhood in the Northeast. "Tiruliruli" represents the point at which these two temporalities meet.

\section{Accurate listening and its context}

Hermeto Pascoal's unusual ability to hear speech as melody appeared at the same age at which he discovered that he had perfect pitch. Perfect pitch is the ability of a person to distinguish or to produce, immediately, a note without having to think or to compare it with any external standard (Deutsch 2006). However, in spite of "seeming like a delicious extra sense that allows the one who possesses it to immediately sing or notate any music in the correct tonality" (Sacks 2007: 126), perfect pitch can also cause problems, as we will see below through a more detailed analysis of the song "Tiruliruli".

When asked about how he discovered that he had perfect pitch, Hermeto Pascoal answered:

I was born that way. I say this because my brother, who died at twenty-eight, Enésio, who played cavaquinho (small, four-stringed instrument similar to a ukulele), was that way (he also had perfect pitch). Because he was listening to the radio, and he knew that I knew the key, and he said to me: 'Hey, isn't that in F major?' And I said: 'Yes'. (Hermeto Pascoal, 1997. Personal interview, Rio de Janeiro, 10 November).

Although perfect pitch seems to be something innate for Hermeto Pascoal, there are a number of factors which may perhaps have contributed to its appearance in this musician. Studies like those by Deutsch (2006: 3) suggest that perfect pitch is more common in musicians, and, among musicians, this occurs more frequently in those who received a musical education starting at a very early age (from age three or four). This seems to be the case for Hermeto Pascoal, since even though he did not receive a formal musical education in childhood, he was born and grew up in a family that provided him with a rich musical environment - his father, brothers, and other relatives were amateur musicians, and until today the Pascoal family preserves the orally transmitted tradition of making music in the family setting. Some relatives have fun rhyming while talking, others sing or play percussive instruments, dance festively, while still others improvise verses and melodies using folk Brazilian rhythms, such as the coco and the embolada. Music is present in the daily life of Pascoal family as a whole (Costa-Lima Neto 2010).

Another factor that may have contributed to the appearance of perfect pitch in Hermeto Pascoal is the visual impairment caused by albinism - although Enésio, 
Hermeto's brother, mentioned in the quotation above, also had perfect pitch without being albino or visually impaired. According to Sacks (2007: 131), "studies estimate that about fifty per cent of children who are born or become blind during childhood have perfect pitch" - the visual sense is partially compensated for by the auditory sense. This could be related to the case of Hermeto Pascoal, not only owing to his albinism, but also because for him exploration of sound was always associated with play. Unable to play in the sun with other children, Hermeto Pascoal seems to have channeled his play entirely towards playing with sound. Even today, Hermeto's search for the unusual is joyful, without the seriousness of some contemporary movements, which over-rationalize the experimental. Elizabeth Travassos (1999, Personal communication) observes that there is an impressive number of popular musicians from the Northeast of Brazil who are blind or have other types of visual impairment - for example Cego Oliveira, Cego Aderaldo, and the blind singers of Campina Grande (in the state of Paraíba). This is an indication that, in addition to the biological factor (the compensation of one sense by another), that in the Northeast - and in other places - music traditionally represents an alternative for social ascent for artists from humble social origins who are visually impaired.

To all this may be added the fact that the region where the musician spent his childhood is inhabited by the Xucuru-Kariri and Kariri-Xocó Indigenous tribes, whose attentive listening to the sounds of nature and the everyday have served as a model for Hermeto Pascoal to further improve his aural perception.

These flutes, these things that I used to do in the forest, really, I was almost like an Indian, I was a mixed Indian. Because there in Lagoa da Canoa, where I grew up, there were Indians everywhere, there was Palmeira dos Índios, and there was the [Porto Real do] Colégio. (Hermeto Pascoal, 1999. Personal interview, Rio de Janeiro, 6 March).

The presence of the Kariri in the region near Lagoa da Canoa is documented from the seventeenth century onward, when missionary settlements were established there - the city of Porto Real do Colégio, for example, is named thus due to the Colégio Jesuíta (Jesuit College), founded in the "Porto Real" (Dantas 1992: 431-456). During the 1940s the Kariri-Xocó and Xucuru-Kariri were scattered throughout the region between the cities of Porto Real do Colégio, on the shores of the Rio São Francisco, at the border between the states of Sergipe and Alagoas, and Palmeira dos Índios, near Lagoa da Canoa. At night, in his house in Olho d'Água da Canoa - an isolated locality, and without electric light - sometimes Hermeto Pascoal would hear the indigenous people in the forest, with their songs and dances of the Toré and, during the daytime, he would imitate them, playing flute, under the trees, in duet with the birds. The Toré (also known as tolê, torém, boré) is a mixture of dance, ritual, song and instrumental music chiefly using flutes and shells ("trumpets"), as well as percussion instruments, such as the maracá ("rattle"). It constitutes a kind of lingua franca of the indigenous people of the Northeast, being used as means for the ethnic groups spread throughout the states in the region (Pankararu, Tumbalalá, Pataxó Hãhãhãe, Kambiwá) to affirm their cultural identity. With the Toré, practitioners seek to establish contact with the enchanted ones, spiritual beings, whom they call upon in order to obtain direction, care, and protection (Grunewald 2005: 13-38; Bastos 2006: 115-130). We will see below how, in the manner of the Toré - a mixture of play and syncretic rite - the "Sound 
of the Aura" seems to seek the sacred through the festive, with the voice and the other instruments as spiritual powers.

It is necessary to point out the importance that these tribes attach to listening, both conceptually and perceptually. Bastos (1978: 78-79) observes that among the Kamayurá (Upper Xingu, in the southern part of the Brazilian Amazon) there is a taxonomy of forms of cognitive knowledge that differentiates the act of understanding (anup) from the act of knowing (cak). The former indicates the knowledge of the general, of the theoretical, while the second designates the knowledge of the particular, based on empirical experience. Shifting the taxonomy from the conceptual to the perceptual, the Kamayura relate the broader understanding (anup) to the sense of listening, while the immediate knowledge (cak), to that of vision. The word napyate, in turn, designates a deaf person, but the word nanuyte (note the phonetic similarity between the two words) corresponds to a pathological condition worse than deafness: the mental alienation - nanuyte means, literally, "the one who do not listen". The appreciation of the sense of listening by the Indians explains their difference to the sensory channels favored by the Western world. To Kamayurá and other Indigenous peoples in Brazil, listening is linked both to language and music, two "radically distinctive attributes of the state of humanity" (Bastos 1978: 78). The importance of hearing to Hermeto Pascoal and to the musicians who played with him is exemplified by the following quote:

Even though we are primarily driven by vision, our sense of hearing remains as the most basic universal way to connect to the world around us. As musicians, being aware of the environment inhabited by music entities as a vibrating field of acoustical energy is crucial for our growth as performers, composers and arrangers. (Santos Neto 2018).

Scholars (Safran quoted by Sacks 2007: 133) argue that perfect pitch (along with synesthesia) is universal in early childhood, until the development of language inhibits it. Statistics shows that the presence of perfect pitch in adults is rare - fewer than one in every ten thousand individuals (Hamilton et al. 2004). Deutsch (2004) states that the proportion of people with perfect pitch increases considerably among speakers of tonal languages, such as Vietnamese or Mandarin (although African Yoruba is also a tonal language, I don't find studies on the proportion of people with perfect pitch among speakers of this language). Due to the rareness of perfect pitch, persons with this ability frequently are met with incredulity by others, as was the case for Hermeto Pascoal when he was in the USA during the 1970s:

For example, Miles Davis, he was on the first floor of his house, on the ground floor, at the time he was forty-five, and Airto (Moreira) told him that I had perfect pitch and he (Miles Davis) said: 'He doesn't know anything', joking. (...) In school (in the USA) they teach the note (the B-flat) for the guy (the trumpeter) to be hammering on it the whole time, in order for it to be sounding inside, to develop his listening more, so that he can be able to solfege and to know the pitch, but this is not worth very much if the guy does not have perfect pitch. What he can do is to sing that note and get the tonality from there. And he, at his school, learned to do that. And so Airto was telling me all of this (translating). (And so, Hermeto asked:) 'Tell him that whatever note he wants, I don't need him to play the note for me, I will produce (sing) the note that he wants'. And then he (Miles) said: 'No, he can't. How? Without me giving a note?' And so I sang B-flat for him, but he had to go up the stairs (the piano was on the upper floor). I joked with him: 'Look, you are getting old, you are going 
to be out of tune, and sing it flat. Whatever happens, I will give you another note, and you play it on the piano. Now it depends on the tuning of your piano, because sometimes I give a note and the note on the piano is out of tune...' (Hermeto Pascoal, 1999. Personal interview, Rio de Janeiro, 6 March).

In order to address the subject of perfect pitch in an academic way, in 1999, I gave Hermeto Pascoal an informal test which, although not having been applied systematically, will at least give us an idea of the kind of hearing that the composer has. I took a little handbell to an interview with him, and asked the musician to identify, by ear, the note of the bell. At the moment of the experiment, with which he kindly agreed to participate, Hermeto Pascoal was seated in front of his electric piano, and as soon as I played the bell, his hand immediately moved in the direction of the note F-sharp, in the high register, pressing the corresponding key several times. Since the electric piano was turned it off, it did not produce any sound. The experiment could have stopped there, since Hermeto Pascoal had already perceived, by ear, the note of the bell, but the musician still did not seem to be satisfied. He turned on the electric piano, and, immediately after having played the key mentioned, said that the sound that he heard on the bell was in fact located between the F-sharp and the adjacent $\mathrm{G}$.

In 2010, I did a computerized spectral analysis of the sound of that bell, that produced a "beat", that is, an interaction between two adjacent frequencies (Cogan 1976: 370-385), close to the note of F-sharp in the equal-tempered system. In fact, there was not just one, but two frequencies in the sound of the handbell, and the "beat" between these two close frequencies resulted in a sound internally out of pitch. Hermeto Pascoal correctly related the sound of the bell to the note F-sharp remember that the electric piano did not help him, since it was turned off at that moment. He was also correct in saying (now playing the piano) that the "note" was, in fact, a frequency between the notes F-sharp and G. As shown by the computerized spectral analysis, one of the two frequencies of the "beat" of the sound of the handbell is $2,976 / 2,979 \mathrm{~Hz}$ and is 9 to 11 cents above F-sharp 6 in the equal-tempered system. The cent system was developed around 1880 by Alexander J. Ellis (1814-1890), in order to measure small differences between intervals of various scales, as well as to study micro-intervals (intervals smaller than a semitone). The cent is ideal for comparing and representing any interval in relation to the system of equal temperament, being used not only by acousticians but also by ethnomusicologists for the study of the micro-intervals found in nonEuropean scales (Henrique 2009: 928-929). Note that 11 cents is about equal to a tenth of a semitone - a semitone is made up of 100 cents. It is a tiny micro-interval, to which Hermeto Pascoal's hearing was sensitive.(4)

The passage below exemplifies other difficulties Pascoal encountered, in this case caused by the constant changes in tuning allowed by the technology of electronic keyboards:

With these electronic keyboards a guy with a perfect ear suffers, because, depending on the pitch of the A, the B-flat is almost B natural, or A. That's why I say: 'If it's A 440 it's this, and if it's 442 it's that'. (Hermeto Pascoal, 1999. Personal interview, Rio de Janeiro, 6 March). 


\section{A musical medicine}

In 1984, fearing that he possessed a kind of "auditory hallucination" that caused him to hear things that in fact did not exist, Hermeto Pascoal finally decided to clear up this story:

Is it possible that this aura sound that, since I was little, I think that people are singing instead of talking, is it possible that it is only my mind that thinks so? And so I got my mental characters to help me. I came up with the idea of taking my old organ (the harmonium) and it was from there (with "Tiruliruli") that everything began. I thought to myself: 'I'm going to do a test'. Generally, in tuning a piano, you play a note, take an octave above, if there is any difference, any little tiny difference, then everyone feels bad, it is terrible. That is when I realized that I was right, precisely because of this. (...) What I do does not only depend on the twelve notes. It depends on my imagination. Playing with conventional instruments is an idiom that you have to use on Earth, if not you can't manage to communicate musically with anyone. The idiom here is conventional. (Hermeto Pascoal, 1999. Personal interview, Rio de Janeiro, 6 March).(5)

As the passage above shows, "Tiruliruli" came from the need that Hermeto Pascoal had to prove to himself that he did not have "hearing problems", and was not a "lunatic", as his mother told him when he was a child. With this objective, the musician - a soccer fanatic - recorded, on cassette tape, a portion of the soccer narration done by the sports announcer Osmar Santos: "Ciscou pra lá, ciscou pra cá, enlouquece seu povo, doutor! Tiruliruli, tiruliruli, e que gooooool!" ("He looked here, he looked there - drive your people crazy, doctor! Tra-la, tra-la, and what a GOAL!"). Since Hermeto Pascoal considers that the "Sound of the Aura" is a composition by the person who is the owner of the voice, note that the authorship of 'Tiruliruli' should be credited to Osmar Santos.

The audio of the narration was subdivided into loops at the studio of Som da Gente, and while the sound engineer played back the recorded tape, Hermeto would play the harmony and melody on his harmonium (an instrument with a sound similar to church organs, an aspect the meaning of which will be explored below), adapting the "conventional" notes of the instrument to the "natural" frequencies of the voice of the sports announcer. Thus, the musician transformed the goal of the player Sócrates, who was known as "doutor" because he was also a medical student, into a "medicine", by using the "conventional idiom of the Earth" (made up of the notes of the equal-tempered system and by the timbres of conventional musical instruments) in order to musically "translate' the nontempered frequencies of the spoken voice, the "natural" instrument par excellence, according to Hermeto Pascoal himself.

The period in which "Tiruliruli" was recorded coincides with that in which Hermeto Pascoal, after breaking with the multinational recording company Warner, started to record discs under his name with the independent Brazilian record label Som da Gente ("Sound of Our People"). The musician returned to the tradition of family music-making, opposing the anonymity of the labor employed by the industry to the formation of a "semitribal" community created through links of vicinity and kinship with the musicians of the Group that accompanied him from 1981 to 1993 (Elizabeth Travassos, 1999. Personal communication). The musicians Itiberê Luiz Zwarg (electric bass, tuba and euphonium), Jovino Santos Neto (piano, keyboards, flutes), Antônio Luis Santana - nicknamed Pernambuco - (percussion), 
Carlos Daltro Malta (saxes, flute, piccolo) and Márcio Villa Bahia (drums and percussion)(6) were so committed to their work that they moved to the vicinity of Hermeto's house in the distant neighbourhood of Jabour, Rio de Janeiro, so they would not lose time with transportation to and from rehearsals. This close and continuous co-existence tightened friendship and family bonds amongst the members of the band, and it also allowed Hermeto Pascoal fully to develop his "Sound of the Aura" (Costa-Lima Neto 2015).

In spite of the fact that the "Sound of the Aura" is not directly related to politics, it is important to note that, in the year that "Tiruliruli" was launched, Brazil was exiting from the military dictatorship that was governing the country between 1964 and 1985. The soccer player Sócrates and the sports announcer Osmar Santos actively participated in the campaign that sought to re-establish the direct vote for president of the Republic, after two decades in which the Brazilian people could not exercise its democratic right to elect a civilian candidate to govern the country. I noted earlier that Hermeto refers to the aura musician as a sound photographer that reveals the melody of speech. This sound photograph, however, register also the "human behavioral process" that produces the musical sound, "shaped by the values, attitudes, and beliefs of the people who comprise a particular culture" (Merriam 1964: 6). In this sense, "Tiruliruli" can be considered as a sound photograph of a decisive moment in the recent history of Brazil, when broad sectors of civil society, including artists, soccer players, fans and sports announcers, allied directly and indirectly in the defense of democracy and of freedom of artistic expression (this dispute between democratic and authoritarian regimes in Brazil is far from over and the battle is currently exasperated).

Beginning with "Tiruliruli", Hermeto Pascoal later came to call this kind of musical composition the "Sound of the Aura", through which he communicates to people a music which they themselves produced, but do not hear - and an image invisible to their eyes:

\begin{abstract}
At that time (when "Tiruliruli" was created) I still had not named it 'aura', but now I know that it is a sound above the head, all the energy is up here (puts his hands above his head). (...) Because the aura around a person is not contained, it is continuous, it does not stop, does not stop moving, all around us, it is us who don't see it, because there are people who want to see with their eyes something that is not meant to be seen with the eyes, it is to be seen with feeling. What is lacking is to develop the perception. (Hermeto Pascoal, 1999. Personal interview, Rio de Janeiro, 6 March. My emphasis).
\end{abstract}

The passage quoted above reinforces the idea that permeates the literature addressing the subject of the musician with visual impairment: "he does not see, will see with other eyes, the eyes within. (...) Hearing will be his path of light" (Reily 2008: 261). In order to perceive the aura, Hermeto Pascoal says it is necessary to "see with feeling", and not with the eyes.

The next quote will be useful in order to glimpse a relation between soccer, spirituality and music:

As in soccer, I always mention soccer, because it inspires me a lot; sometimes a coach takes a player from a position, and the player is not playing at all, and moves him to his true position, because the other coaches had no perception, and did not put the guy in the position that he was able to play. And so in music it is the same way. (Hermeto Pascoal, 1999. Personal interview, Rio de Janeiro, 6 March). 
To "change the position of the players" and access other dimensions of the sense perceptions of the human being, in the "Sound of the Aura" Hermeto Pascoal changes the nature of speech, making it equal to song, while he dribbles around reason in order to feel the "sound above the head". The goal or objective of this game, a mixture of play and ritual, is spiritual:

The 'Sound of the Aura' is a thing that comes from within the energy of people, it is something that is very spiritual. The thing is so spiritual, from the spirit and body of the person, that for the person himself, since it is something that comes from the person, it is nothing new. (Hermeto Pascoal, 1999. Personal interview, Rio de Janeiro, 6 March).

\section{Description, transcription and analysis of "Tiruliruli"}

The only true notations are the sound-tracks on the record itself (Bartók quoted by Seeger 1958: 187).

In the recording included on the LP issued in 1984, the entire spoken passage is repeated three times (for each of these three times, the portions "Ciscou... doutor" and "tiruliruli, tiruliruli" are repeated twice, in a loop), with a total duration of one minute. First we hear the voice of Osmar Santos, a cappella; then the same spoken passage, harmonized with chords; and finally, Hermeto Pascoal adds the melody, playing one note on the harmonium for each spoken syllable, with the exception of the monosyllable "goal", which slides downward in a long glissando between the notes E and C. In "Tiruliruli" there is a continuum between the poles of "natural" (narration/spoken) and "conventional" (musical instruments/song). In the first part of the music the poles are separate, in the second they are superimposed, and in the third, they are fused. At the end of the process, the musicality of the spoken voice is revealed and it becomes a song or melody accompanied by chords, thus constituting a third entity that is no longer either "nature" or "convention" but the paradoxical fusion of the two.

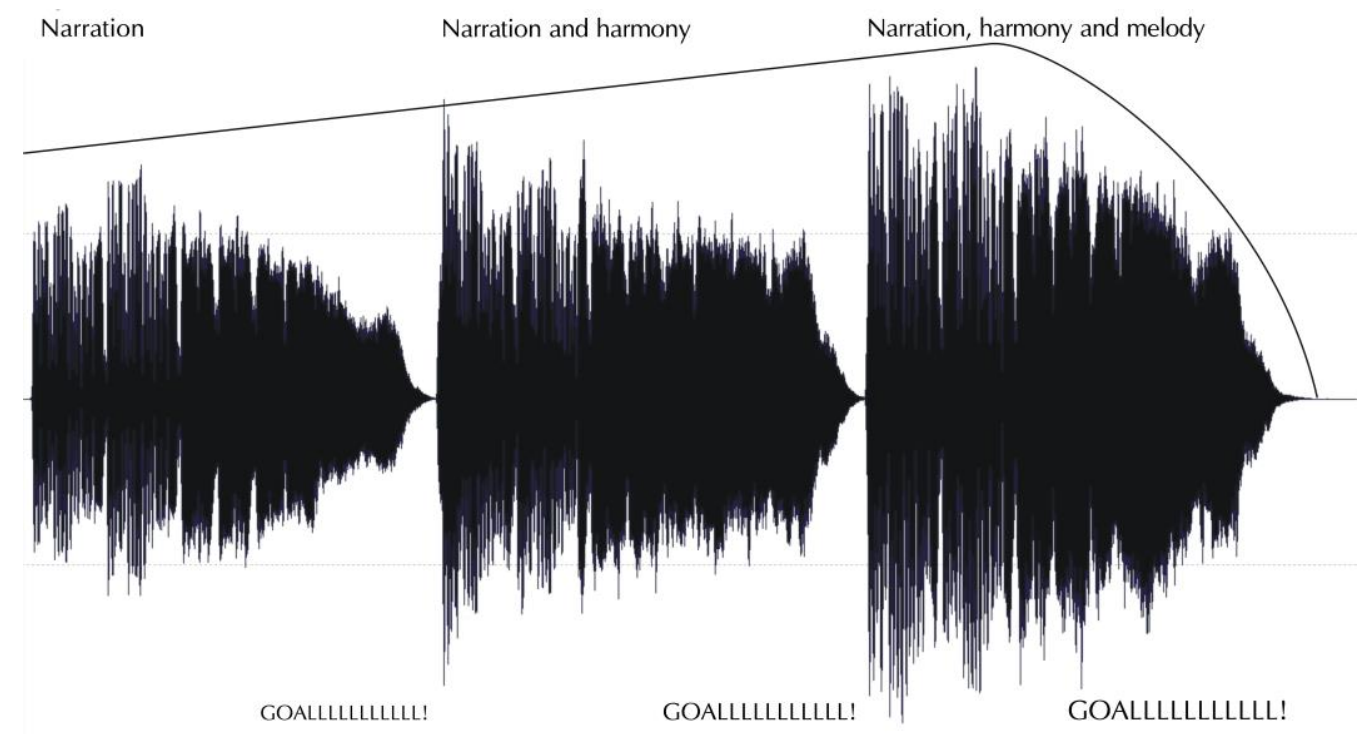

FIGURE 1. "Tiruliruli". Computer-generated dynamic envelope. 
Listening to the recording done has the impression that there is a continuous narration that culminates with the goal by Sócrates, but in doing the spectral analysis of "Tiruliruli" I observed that the image generated on the computer showed a gap separating two portions of the narration, as if someone had cut and pasted the audio tape. In fact, as is noted on the back cover of the 1984 LP, there was editing done at Nosso Estúdio, in São Paulo, by Hermeto Pascoal and Marcus Vinícius, the sound engineeer for Som da Gente. On the image of the spectrogram we can see the cesuras separating the loops mentioned above, and the gaps between the passages "Ciscou pra lá..." and "tiruliruli...". The editing done at the studio brought together two passages that originally were separate in the soccer narration.

I present in Figure 2 a transcription into score of the recording of "Tiruliruli", also using comparative data obtained using the program Sonic Visualiser (sonicvisualiser.org). In order to represent the "quasi-unison" (Borém 2010: 32) of voice and harmony, I have added, immediately above the musical system, symbols in brackets indicating the non-tempered frequencies of the spoken voice $(\mathrm{C} \# 3+11$ cents, E3 - 41 cents, F3 -26 cents etc.). The reader will see that none of the notes played by the harmonium corresponds exactly to the voice of Osmar Santos, and are sometimes lower, or higher, in a way analogous to what took place in the experiment mentioned above which I carried out with Hermeto Pascoal, in which two closely adjacent frequencies from the sound of the handbell were a few cents from the note of F\#6 produced by the piano.

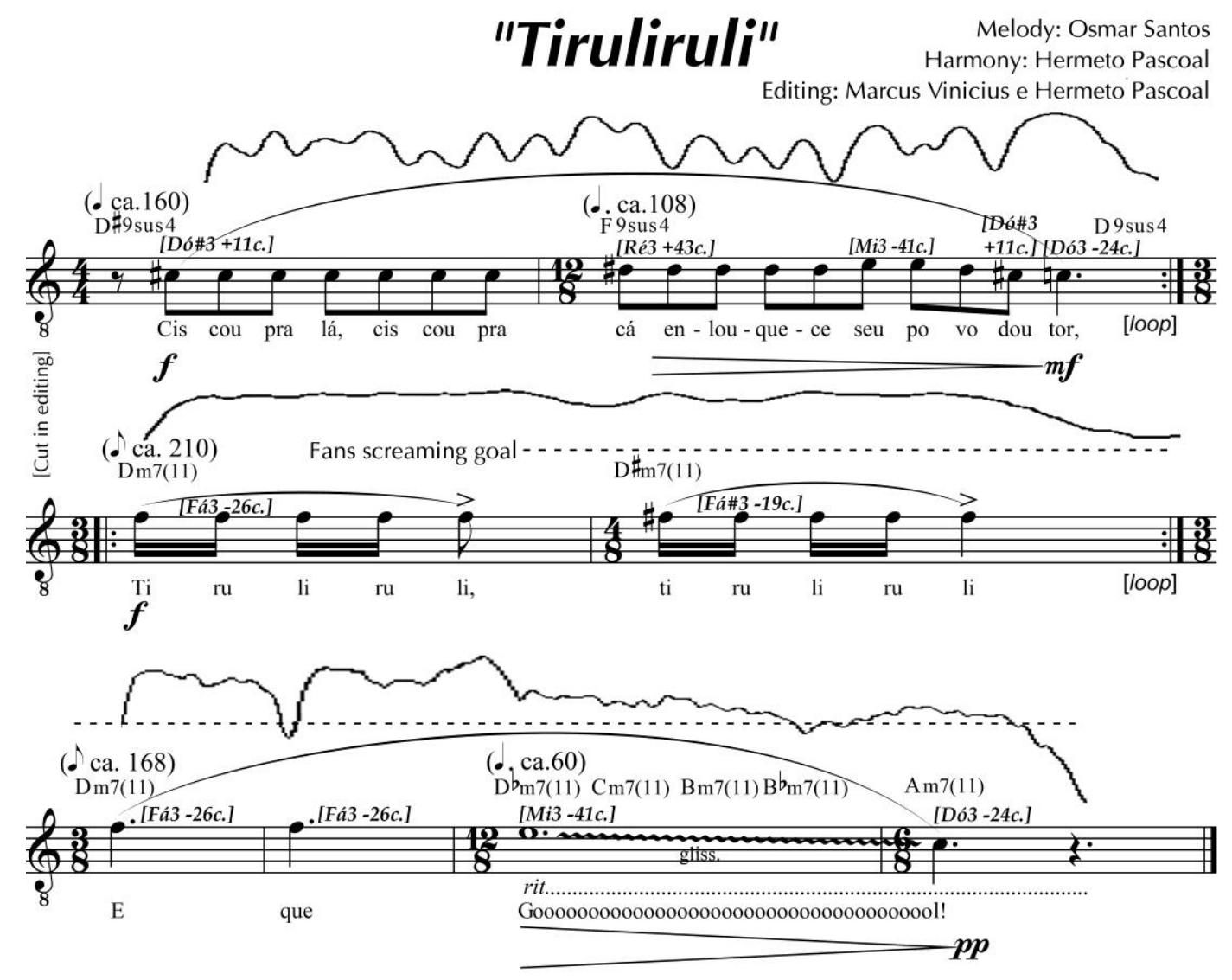

FIGURE 2. Transcription into score of the recording of "Tiruliruli" (with computergenerated graph of dynamics). 
Since the spoken voice does not follow a clearly defined pulse or regular speed, the score shows various changes of meter and tempo (noted metronomically). Brusque changes of meter take places (2, 3 and 4 beats), with alternation of simple and compound rhythms. The harmony played by Hermeto Pascoal on the harmonium is not functional, and colours the melody synesthetically, using only two types of chords - the first, with a seventh, suspended fourth and ninth, and the second, minor third, with seventh and eleventh, represented in the score by means of numbers. The dynamics, in turn, are indicated with the symbols of conventional notation, and at the same time, by means of the graph generated by the computer, better suited for representing the microvariations of intensity for the spoken voice. I inserted the graph above the metronomic indications of agogics (emphasis by duration).

As the ethnomusicologist Charles Seeger (1958) observed in an important article, vocal performances present variations in pitch, timbre and dynamics which are difficult to represent graphically in a score. Trying to get around this problem, as if anticipating certain modern musical software, Seeger invented a pioneering apparatus, the Melograph Model C (Seeger 1957; 1962), capable of mechanically representing sung melodies in real time. The analysis of "Tiruliruli" presents the same difficulties noted by Seeger, but with some additional aggravating factors. The recorded voice of Osmar Santos sounds rather noisy due to the saturation produced by the voice shouted into the microphone, along with the distortions from the radio transmission, the noises of the recording on tape cassette, and finally, the buzzing of the fans at the soccer stadium.

The level of noise makes it even more difficult to perceive the pitch of each spoken syllable, especially when the words in the narration are linked closely together, as in the initial portion (repeated in a loop): "Ciscou pra lá, ciscou pra cá, enlouquece seu povo, doutor". In this phrase only the final syllable of the word "doutor", longer than the rest is sustained at a pitch that is clearly perceptible (C3 24 cents) - with a subtle descending microtonal portamento. The faster the rhythm of speech, the more difficult it becomes to perceive its pitches. Curiously the same frequency from the previous portion ( $\mathrm{C} 3$ - 24 cents) appears at the end of the glissando of "gol". In both portions there is a pattern of intonation verifiable through the descending melodic curve and through the conclusion of the two phrases, always with a decrescendo of dynamics.

It is important to perceive patterns of pitches produced by improvisation in the voice of Osmar Santos, which can be connected, in an embryonic way, to the principal "conventional" musical systems of the planet. For example, in the passage "Ciscou pra lá, ciscou pra cá, enlouquece o seu povo, doutor", the frequencies of the voice and the corresponding notes of the harmonium (C3, C\#3, D\#3, E3) could be analyzed as belonging to the first tetrachord of a superlocrian scale or, also to a symmetrical scale (C, C-sharp, D-sharp, E, F-sharp, G; A; B-flat, C) (Persichetti 1961). The notes (F3, F\#3) of the portion made up of the onomatopoeias "tiruliruli, tiruliruli", in turn, seem to traverse a chromatic scale, while the glissando on the word "gol", finally, runs microtonally through all the commas between E3 and C3. The "Sound of the Aura" takes in modalism, tonality, atonality, and noise, reintroducing the particular into the universal: music ("conventional") into sound ("natural").

The rhythmic-melodic climax takes place when Osmar Santos says his catchphrase "tiruliruli, tiruliruli", whose rhythm and melodic contour seems to be related to the chorus of an Old Portuguese folk song titled "Tiro Liro Liro", which 
became internationally known in the 1940s, when it was sung by Amália Rodrigues, and in the 1980s, in Brazil, by Roberto Leal. The fans scream goal, in the background, but the announcer only announces the goal seconds later, in a long descending glissando harmonized chromatically by the chords of the harmonium, after which "Tiruliruli" comes to its conclusion. There is thus a sort of canon between, on the one hand, the noisy mass of sound produced by the fans and, on the other, the voice of Osmar Santos, the first anticipating the scream of goal which then will reverberate as an echo in the voice of the announcer, full of emotion. The third voice in the vocal-instrumental texture is that of the "photographer of the aura", that is, Hermeto Pascoal, who, playing his church harmonium, is in dialogue with Osmar Santos, the players, and the fans.

\section{Conclusion}

This article has explored several musical, psychological, socioeconomic, cultural, political and spiritual aspects related to "Tiruliruli", the first "Som da Aura" recorded by Hermeto Pascoal. By preserving perfect and microtonal pitch and the aural and synesthetic perception of sound, which were manifested early on in his childhood in the rural Brazilian Northeast, Hermeto Pascoal also retains the sense of play of the child, as well as the notion of music as a familiar and communitarian social practice, in which the figures of the popular artist and the audience sometimes are mixed together. The "Sound of the Aura" was precisely a way in which Hermeto Pascoal was trying to resolve the tension caused by the fact that he possessed something that since childhood had not been shared with other people. The example of Hermeto reveals how "the real question with respect to perfect pitch is not why some people have it, but why it is not universal" (Deutsch quoted by Sacks 2007: 129). "Tiruliruli" thus serves as a kind of musical therapy that liberates the composer from his own exceptionality, removing him from isolation and allowing him to communicate something that until that point was solely individual. The "medicine", in this case, was found in daily life and in that which is the most prosaic: the spoken voice, the battery-powered transistor radio, the sports announcer, and the fans - soccer as popular religion.

Composed after Hermeto Pascoal had terminated his Warner Bros. contract, and at the end of the military dictatorship of 1964-1985, "Tiruliruli" also exemplifies the resistant socio-musical discourse of Hermeto Pascoal. The period 1981-1993 meant, for Hermeto Pascoal and his Group, a time of economic censorship determined by the market, when major labels began to invest in genres of greater commercial appeal, leaving out many artists whose music was considered noncommercial. Perhaps "Tiruliruli" served not only to allow Hermeto to liberate himself from old worries in relation to his own hearing, but also as a kind of an experimental "protest song" against economic and political domination - it wouldn't be by coincidence that "Tiruliruli" culminates with a manifestation that no one can hold back or censure: the cry of "Goal!".

Through the "Sound of the Aura" Hermeto Pascoal seems to reinvent the sociocultural and economic traditions of the Northeast, based on family units and on the autonomous activities of artisans. By inserting these communitarian practices into industrial modernity the musician ends up inverting the principles that govern the capitalist system. In the extreme case - that is, if people started hearing their own speech as a sung melody - music would lose its status as merchandise, since it could be created and exchanged for free by every person. Consumers would take 
on the position of producers, free from the control of industry and the political censorship.

What began as an intuitive experiment (with "Tiruliruli") later became a musical utopia that aims to transform the terrestrial into the transcendent. The goal of the "Sound of the Aura" is to awaken people from their normal state of auditory unconsciousness to a kind of altered state of self-awareness, thus realizing the musicality of speech and of the world around us. Based on a popular poetic tradition of an enchanted and prolific nature, of hyperbolic abundance, Hermeto Pascoal moves from the oral to the aural, and makes use of speech ("natural") as raw material for song ("conventional"). Superimposing the microtonal frequencies of the spoken voice upon the notes of the system of equal temperament and of conventional instruments, the "Sound of the Aura" is the hybrid expression of a feeling of sociability, through which Hermeto Pascoal uses recordings on disc in order to share new modes of listening with all human beings who speak, or rather, sing.

\section{Endnotes}

(1) The complete name of the brazilian soccer player was Sócrates Brasileiro Sampaio de Souza Vieira de Oliveira (1954-2011).

(2) It is common practice in Brazilian academic writing for well-known public figures, such as Hermeto Pascoal, to be referred to by their Christian names. This practice will be followed sometimes in this article.

(3) Additionally, see Hermeto Pascoal playing in duo with the animals in "Hermeto Pascoal no Zoo". <https://www.youtube.com/watch?v=Y10Ewgcqky8\&t=85s>. Accessed 12 February, 2020, extracted from the documentary by Yves Billon (1997).

(4) In order to make available the data related to the mentioned experiment, I posted on YouTube the audio of the sound of the handbell and computer generated images. See Costa-Lima Neto, Luiz (2011): "Um experimento com a escuta de Hermeto Pascoal: música e sociedade para além das nota $\$$ ". [Online video] $<$ https://www.youtube.com/watch?v=P7uB565y3ml>. Accessed 13 August, 2020.

(5) On attempts to create microtonal instruments and microtonal musical systems in modern art music, see Forkert (2020: 75-118). For a microtonal electronic instrument launched recently, see dolomuse (2020): “'OUTヨR WORLDS' - PolyChromatic Music with the Lumatone". [Online video]

$<$ https://www.youtube.com/watch?v=AFSF5NugG2Q\&t=53s $>$. Accessed 22 October, 2020.

(6) In 1988, Hermeto's son, Fabio Pascoal (percussion), joined the Group.

\section{Acknowledgments}

This article was originally published as a journal article in Claves, vol. 8 (2013) as "O cantar natural de Hermeto Pascoal: compartilhando vozes e escutas por meio das gravações em disco - Parte I." 


\section{References}

\section{Bibliography}

Baron-Cohen, S. and Harrison, J. E,. 1997. Synesthesia: classic and contemporary readings. Massachusetts: Blackwell Publishers.

Bastos, R.J. de Menezes. -

1978. A Musicológica Kamayurá: para uma antropologia da comunicação no

Alto-Xingu. Brasília: Fundação Nacional do Índio.

2006. O índio na música brasileira: recordando quinhentos anos de esquecimento. In Músicas africanas e indígenas no Brasil, edited by

Rosângela Pereira de Tugny and Ruben Caixeta de Queiroz. Belo Horizonte: Editora UFMG.

Borém, F. and Araújo, F., 2010. Hermeto Pascoal: experiência de vida e a formação de sua linguagem harmônica. Per Musi, Belo Horizonte, n 22, 22-43.

Cogan, R. 1976. Sonic Design. New Jersey: Prentice-Hall.

Costa-Lima Neto, L. -

2000. The Experimental Music of Hermeto Pascoal and Group (1981-93): a

Musical System in the Making. British Journal of Ethnomusicology, 9/1, 119142.

2010. O cantor Hermeto Pascoal: os instrumentos da voz. Per Musi, n.22, 4462.

2011. The Musical Universe of Hermeto Pascoal. Popular Music and Society, 34:02, 133-161.

2015. The Experimental Music of Hermeto Pascoal and Group (1981-1993):

Conception and Language. Translation Laura Coimbra and Stephen

Thomson Moore. Hillsdale, NY: Pendragon Press.

Dantas, B. et al., 1992. In História dos índios no Brasil, edited by Manuela

Carneiro da Cunha. São Paulo: Companhia das Letras.

Deutsch, Diana et al. -

2004. Absolute pitch, speech and tone language: some experiments and a proposed framework. Music Perception. 21, 339-356.

2006. The Enigma of Absolute Pitch. Acoustics Today, 2/4, 11-19.

Forkert, A. 2020. Microtonal restraint. Journal of the Royal Musical Association, 145/1, 75-118.

Grunewald, R. de Azeredo, 2005. Toré: Regime encantado do índio do Nordeste. Recife: Fundação Joaquim Nabuco.

Hamilton, R. H., Pascual-Leone, A. and Schlaug, G., 2004. Absolute pitch in blind musicians. NeuroReport, 15/5, 803-806.

Henrique, L., 2002. Acústica Musical. Lisboa: Fundação Calouste Gulbenkian.

Medeiros, J., 2018. A historical perspective on Música Popular or Popular

Portuguese Music. Master Thesis. San Francisco State University.

Merriam, A. P., 1964. The Anthropology of Music. Illinois: Northwestern University Press.

Pascoal, H., 2000. O Calendário do Som. São Paulo: Editora Senac-Itaú Cultural.

Persichetti, V., 1961. Armonia del Siglo XX. Madrid: Real Musical.

Reily, L., 2008. Músicos Cegos ou Cegos Músicos: Representações de Compensação Sensorial na História da Arte. Campinas: Cadernos Cedes, 28/75, 245-266. 
Sacks, O., 2007. Alucinações musicais: Relatos sobre a música e o cérebro. São Paulo: Companhia das Letras.

Santos Neto, J., 2018. Notes from the Jabour School: multidimensional harmonic models for improvisation, composition and arrangement from Hermeto

Pascoal's Grupo in Rio de Janeiro. Ethnomusicology Review. (Online)

Seeger, C. -

1957. Toward a Universal Music Sound-Writing for Musicology. Journal of the International Folk Music Council, 9, 63-66.

1958. Prescriptive and Descriptive Music-Writing. The Musical Quarterly, 44/2, 184-195.

1962. The Model b Melograph. A Progress Report. Journal of the International Folk Music Council, 14, 168.

\section{Discography}

Airto -

1970. Natural Feelings. Buddah Records.

1971. Seeds on the Ground. Buddah Records.

Hermeto Pascoal. -

1967. "O Ovo", Quarteto Novo. EMI.

1972. "Velório", Hermeto. Buddah Records.

1973. "Sereiarei", A música livre de Hermeto Paschoal. PolyGram.

1973. "O Gaio da roseira", A música livre de Hermeto Paschoal. PolyGram

1977. "Slaves Mass", Slaves Mass. USA. Warner Bros.

1977. "Escuta meu piano", Slaves Mass. USA. Warner Bros.

1979a. "Quebrando tudo", Hermeto Pascoal ao vivo em Montreux. WEA

Brasil.

1979b. Zabumbê-bum-á. WEA Brasil.

1980. "Dança da Selva na Cidade Grande", Cérebro magnético. WEA Brasil.

1982. "Cores", Hermeto Pascoal e Grupo. Som da Gente.

1984. "Tiruliruli", Lagoa da Canoa - Município de Arapiraca. Som da Gente.

1984. "Vai mais, garotinho", Lagoa da Canoa - Município de Arapiraca. Som

da Gente

1985. Brasil Universo. Som da Gente.

1987. Só não toca quem não quer. Som da Gente.

1989. Mundo verde esperança. Som da Gente.

1992. "Pensamento positivo", Festa dos Deuses. Polygram.

1992. "Três coisas", Festa dos Deuses. Polygram.

1992. "Aula de natação", Festa dos Deuses. Polygram

1992. "Quando as aves se encontram nasce o som", Festa dos Deuses.

Polygram

1999. Eu e eles. Rádio MEC.

2002. Mundo Verde Esperança. Rádio MEC.

2008. "Asakusa Market", In Miniatures 2 - A Sequence of Sixty Tiny

Masterpieces, edited by Morgan Fisher. Cherry Red Records

2017. "Som da Aura", Mundo dos sons. Selo SESC.

Miles Davis. 1970. Live Evil. Sony. 


\section{Videography}

L'Allumé Tropical. 1997. Dir. Yves Billon, Les Films du Village La Cinquième. A pessoa é para o que nasce. 2004. Dir. Roberto Berliner, Tv Zero e Petrobrás.

\section{Online Video}

Costa-Lima Neto, Luiz (2011): "Um experimento com a escuta de Hermeto Pascoal: música e sociedade para além das nota \$". [Online video] $<$ https://www.youtube.com/watch?v=P7uB565y3ml>. Accessed 13 August, 2020.

dolomuse (2020): "'OUTヨR WORLDS' - PolyChromatic Music with the Lumatone". [Online video] $<$ https://www.youtube.com/watch?v=AFSF5NugG2Q\&t=53s $>$. Acessed 22 October, 2020.

\section{Interviews}

Hermeto Pascoal, 1997. Personal interview. Rio de Janeiro, 10 November. Hermeto Pascoal, 1999. Personal interview. Rio de Janeiro, 6 March. Santos Neto, Jovino. E-mail to the author, 6 October, 2009. Travassos, Elizabeth. Personal communication, 29 April, 1999. 